\title{
Potential Bone Regenerative Effects of DFDBA, Simvastatin and Platelet Rich Fibrin, Radiographically and Histologically of Intra- Bony Periodontal Defects in White New Zealand Rabbits
}

\author{
Asma M. Serag El-dien ${ }^{1}$, Shereen Fathy ${ }^{1}$, Yasmine Alaa EL-din ${ }^{2 *}$ \\ ${ }^{1}$ Department of Oral Medicine and Periodontology, October 6 University, Cairo, Egypt; ${ }^{2}$ Department of Oral and Maxillofacial \\ Pathology, Histopathology, October 6 University, Cairo, Egypt
}

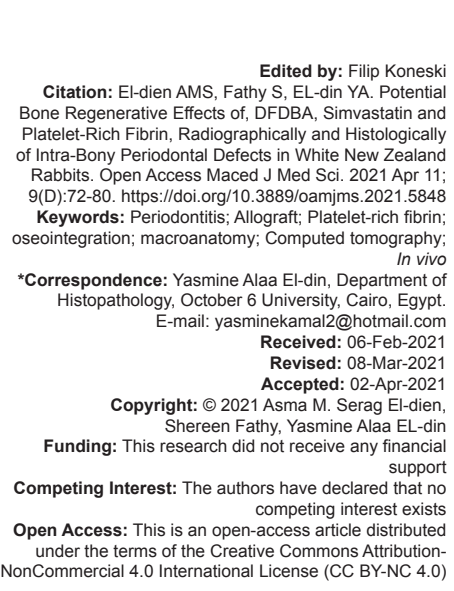

Introduction

Periodontitis is considered a chronically multifactorial inflammatory disease that is characterized by the gradual destruction of dental supportive apparatus and one that is related to plaque biofilms [1]. This disease is caused by specific microorganisms leading to progressive destruction of the periodontal ligament and clinical attachment loss or pocket formation, recession, or both within the alveolar bone [2], [3]. Various graft materials have been used to treat bone defects, but nowadays all the selective materials have their advantages and drawbacks. Consequently, bone repair and replacement have been developed with advanced improvements of orthopedic technologies and biomaterials of superior properties [4].

Demineralized Freeze-Dried Bone Allograft (DFDBA) is considered as one of the most common grafts recently used with good properties of osteoinduction and osteoconduction [5]. It has the great advantage of pockets healing and probing depth decrease. In addition, it helps in the formation of new bone and cementum and so it has been suggested as an effective regenerative substitute for bone defects [6].

Various researchers have found that statin can enhance new bone formation effectively by stimulating BMP-2 genes [7]. The formation of new bone involves producing a new bone matrix by an osteoblast and its mineralization. Moreover, Simvastatin is considered a cholesterol-lowering drug that has produced effective results in promoting bone healing [8].

Platelet-rich fibrin (PRF) is an autologous platelet concentrate that consists of cytokines, platelets, leukocytes, and circulating stem cells and their clot, forming a strong natural fibrin matrix [9]. It has been effective in bone regeneration and specifically used with oral and maxillofacial bone [2]. The regenerative abilities of PRF to the growth factors are released by the platelets entrapped within, such as platelet-derived growth factor and transforming growth factor. These factors can promote periodontal regeneration by stimulating specific cell differentiation and proliferation in a specific manner [10].

Accordingly, this study was conducted to clarify and to evaluate the potential regenerative effects 
of these commonly used materials on the treatment of intra-bony periodontal defects in experimentally created mandibular bony defects. There were previous studies which have highlighted one or two of these materials, but not a combination of these materials along with an evaluation of their effects. Moreover, to the best of our knowledge, this study is the only one in the literature to evaluate the macroanatomy of the materials radiographically and histologically within the same study.

\section{Materials and Methods}

\section{Experimental animals}

Twenty-seven mature male white New Zealand rabbits aged 7-8 months with a mean weight of $2.5 \mathrm{~g}$ were used in this study with all of the ethical principles being highly observed. This study was approved by the Research Ethics Committee at the Faculty of Dentistry, October 6 University, Giza, Egypt (No. RECO6U/1-2020). The animals were equally divided into three groups as shown in Table 1. Before initiating the procedures, all of the rabbits were separated from each other and then acclimatized to the laboratory environment for 5 days. They were fed with a special pelleted commercial diet. The animals were anesthetized by intramuscular injection of $10 \%$ ketamine hydrochloride and $2 \%$ xylazine. The surgical area was disinfected using 10\% Povidone-iodine solution and the hair in the animals' head was shaved. Then the area was isolated and once again disinfected.

Study design of the Experimental Groups and induction of periodontal defects is shown in Table 1.

\section{Steps of surgical field preparation in rabbits}

The surgical field was prepared by being carefully shaved then sterilized using ethanol $70 \%$. A $5 \mathrm{~cm}$ full-thickness incision was made in the skin and the underlying muscles to expose the interdental area between the mandibular first and second molars of all rabbits without vertical incisions. After retraction of the flap corono-apically, 1- osseous-wall defect was then induced by exposing the distal surface of the distal root of the first molar and mesial surface of the mesial root of the second molar. The measurements of the defect were as following: $10 \mathrm{~mm}$ corono-apical (measured from the cementoenamel junction to the most apical edge

Table 1: The preparation of fifty-four intra-bony defects (six defects in each group) are illustrated below

\begin{tabular}{|c|c|c|c|c|c|c|c|c|c|c|c|c|c|c|c|c|c|c|}
\hline & \multicolumn{6}{|c|}{$\begin{array}{c}\text { CT Follow up } \\
\text { (+ Pathology Follow up till } 3 \text { (Till } 2 \text { weeks) }\end{array}$} & \multicolumn{5}{|c|}{$\begin{array}{l}\text { Pathology Follow up } \\
\text { ( Till } 2 \text { weeks ) }\end{array}$} & \multicolumn{7}{|c|}{$\begin{array}{l}\text { Pathology Follow up } \\
\text { (Till 3weeks) }\end{array}$} \\
\hline $\begin{array}{l}\text { Materials } \\
\text { used }\end{array}$ & \multicolumn{2}{|c|}{ A) DFDBA } & \multicolumn{2}{|c|}{ B) Simvistatin } & \multicolumn{2}{|c|}{ C) PRF } & \multicolumn{2}{|c|}{ D) $A+C$} & \multicolumn{3}{|c|}{ E) $B+C$} & $\begin{array}{l}\text { F) }-\mathrm{Ve} \\
\text { (control) }\end{array}$ & & & & & & \\
\hline Rabbits & \multicolumn{2}{|c|}{ R1 } & \multicolumn{2}{|c|}{ R2 } & \multicolumn{2}{|c|}{ R3 } & \multicolumn{2}{|c|}{ R4 } & \multicolumn{3}{|c|}{ R5 } & R6 & \multicolumn{2}{|c|}{ R7 } & \multicolumn{2}{|c|}{ R8 } & \multicolumn{2}{|c|}{ R9 } \\
\hline Side & $\mathrm{R}$ side & L side & R side & L side & $\mathrm{R}$ side & L side & $\mathrm{R}$ side & L side & $\mathrm{R}$ side & L side & $\mathrm{R}$ side & L side & $\mathrm{R}$ side & L side & $\mathrm{R}$ side & L side & $\mathrm{R}$ side & \\
\hline $\begin{array}{c}\text { Tt } \\
\text { modalities }\end{array}$ & $\begin{array}{c}\text { A } \\
\text { Defect } \\
\text { filled } \\
\text { with } \\
\text { DFDBA }\end{array}$ & \begin{tabular}{|c|} 
\\
Defect \\
filled \\
with \\
Simv
\end{tabular} & \begin{tabular}{l}
\multicolumn{1}{c}{ C } \\
Defect \\
filled \\
with \\
PRF
\end{tabular} & $\begin{array}{c}\text { D } \\
\text { Defect } \\
\text { filled } \\
\text { with } \\
\text { DFDBA } \\
+ \text { PRF }\end{array}$ & $\begin{array}{c}\text { E } \\
\text { Defect } \\
\text { filled } \\
\text { Simv. } \\
\text { +PRF }\end{array}$ & $\begin{array}{c}\text { F } \\
\text { Defect } \\
\text { filled } \\
\text { with } \\
\text {-ve }\end{array}$ & \begin{tabular}{|c|} 
A \\
Defect \\
filled \\
with \\
DFDBA
\end{tabular} & $\begin{array}{c}\text { B } \\
\text { Defect } \\
\text { filled } \\
\text { with } \\
\text { Simv. }\end{array}$ & \begin{tabular}{|c|} 
C \\
Defect \\
filled \\
with \\
PRF
\end{tabular} & \begin{tabular}{|c|} 
D \\
Defect \\
filled \\
with \\
DFDBA \\
+ PRF
\end{tabular} & \begin{tabular}{|c} 
E \\
Defect \\
filled \\
Simv. \\
+ PRF
\end{tabular} & $\begin{array}{c}\text { F } \\
\text { Defect } \\
\text { filled } \\
\text { with } \\
-v e\end{array}$ & $\begin{array}{c}\text { A } \\
\text { Defect } \\
\text { filled } \\
\text { with } \\
\text { DFDBA }\end{array}$ & \begin{tabular}{|c|} 
B \\
Defect \\
filled \\
with \\
Simv.
\end{tabular} & \begin{tabular}{l}
\multicolumn{1}{c}{ C } \\
Defect \\
filled \\
with \\
PRF
\end{tabular} & $\begin{array}{c}\text { D } \\
\text { Defect } \\
\text { filled } \\
\text { with } \\
\text { DFDBA } \\
+ \text { PRF }\end{array}$ & \begin{tabular}{|l} 
E \\
Defect \\
filled \\
Simv. \\
+PRF
\end{tabular} & \begin{tabular}{|c|} 
\\
Defect \\
filled \\
with \\
-ve
\end{tabular} \\
\hline $\begin{array}{c}\text { Group } 3 \\
\text { Follow up } \\
3 \text { weeks }\end{array}$ & & & & & & & & & & & & & & & & & & \\
\hline $\begin{array}{c}\text { Group } 2 \\
\text { Follow up } \\
2 \text { weeks }\end{array}$ & & & & & & & & & & & & & & & & & & \\
\hline $\begin{array}{c}\text { Group } 1 \\
\text { Follow up } \\
1 \text { weeks }\end{array}$ & & & & & & & & & & & & & & & & & & \\
\hline
\end{tabular}

Keywords: -

R for rabbit $\quad$ A, B, C...F for treatment modalities 
of the defect) and $4 \mathrm{~mm}$ deep (buccolingual direction) measured from the surface of the alveolar bone to the lingual surface of the defect [11], [12].

\section{PRF preparation}

To prepare PRF, $5 \mathrm{~mL}$ blood samples were collected from each rabbit before sedation using capillary tubes from the inner canthus of the eye into syringes without anti-coagulants then centrifuged at 30.000 RPM for 15 mins. PRF was picked up and compressed between two sterile glass slides to form a thin membrane and divided into two pieces; one was used as a membrane, and the other was cut into pieces to be mixed with either DFDBA allograft* or Simvastatin**

*Demineralized corticocancellous Allograft Powder STERILE R made in Austria

**Zocor Singulair

\section{defects}

\section{Application of different materials to the}

Intra-bony periodontal defects were filled with the different materials according to the previously mentioned groups in the study design (Figure 1a-c). Finally, the periosteal flap was returned to its original location, and the periosteum and the skin were separately sutured with resorbable 0.4 Vicryl sutures in two internal and external layers.

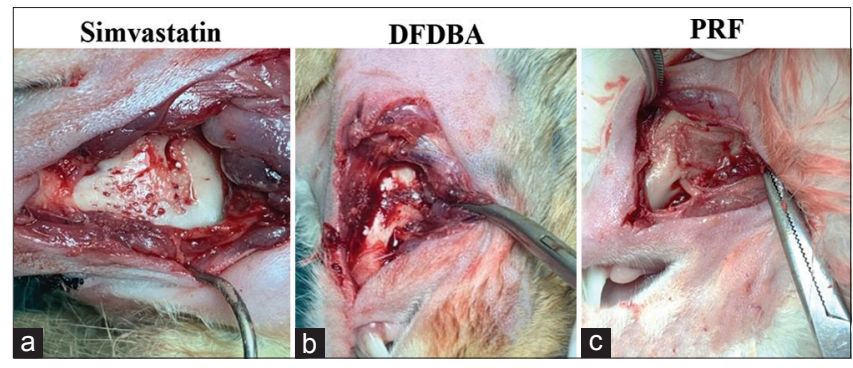

Figure 1. (a-c) A photo showing induction of materials to the defects

\section{Post-operative management and assessment of the rabbits}

After the surgical operation, a pharmaceutical regimen consisting of subcutaneous injections of antibiotics (0.6 mL enrofloxacin) and analgesic $(0.1 \mathrm{~mL}$ ketoprofen) was daily administered for 3 days. The rabbits received a conventional diet. Furthermore, they underwent daily routine examinations to evaluate their post-operative status.

\section{Animal euthanization}

Nine rabbits had been euthanized 1 week after the macroanatomy and histological examinations. The rest of 27 rabbits had been euthanized by the end of our study by intravenously administering $2 \mathrm{ml}$ of thiopental solution. The defect sites were sectioned by a saw. Following that, a notch was produced in the occipital area to assist in identifying the direction of the defects. Finally, the defects were dissected and prepared for histological examination.

\section{Histological examination}

Histologic sections with a thickness of $6 \mu \mathrm{m}$ were prepared from each defect that contains an intact border of the bone. Next, the samples were routinely stained with hematoxylin and eosin. For histological evaluation of the healing process, Emery's histological healing criteria were used [13]. Following is Table 2 illustrating Emery's criteria:

Table 2: Emery's histological healing criteria

\begin{tabular}{ll}
\hline Score (point) & Tissue present \\
\hline 0 & Empty cavity \\
1 & Fibrous tissue only \\
2 & More fibrous tissue than fibrocartilage \\
3 & More fibrocartilage than fibrous tissue \\
4 & Fibrocartilage only \\
5 & More fibrocartilage than bone \\
6 & More bone than fibrocartilage \\
7 & Bone only \\
\hline
\end{tabular}

\section{Results}

\section{Macroanatomy findings}

The defects in the rabbits were detected following 1 week and 3 weeks of euthanization:

\section{After 1 week}

The DFDBA applied in the defect showed good bone regenerative effects in comparison to the effects of simvastatin only, which showed less regenerative effects in bone formation and healing. The effects of PRF only after 1 week did not bring about impressive results in terms of treating the defect compared the control left side of the same rabbit. The combination of DFDBA and PRF showed excellent healing results. Simvastatin + PRF showed better results in terms of bone regeneration in comparison to the control left side of the same rabbit (Figure 2a-f). (Red circles surrounded the defect in the figures).

\section{After 3 weeks}

The DFDBA sections showed good healing results in comparison to the effects of the simvastatin only, which showed less bone regenerative effects. In comparison, simvastatin is still less effective with PRF than it is with DFDBA. The left control side showed that a normal healing process is good and in progress. The PRF only in the right side brought unsatisfactory results after 21 days and remained so. The DFDBA+PRF combination in the left side of the same rabbit showed excellent results and almost completed healing of the defect after 3 weeks (Figure 2a-f). 


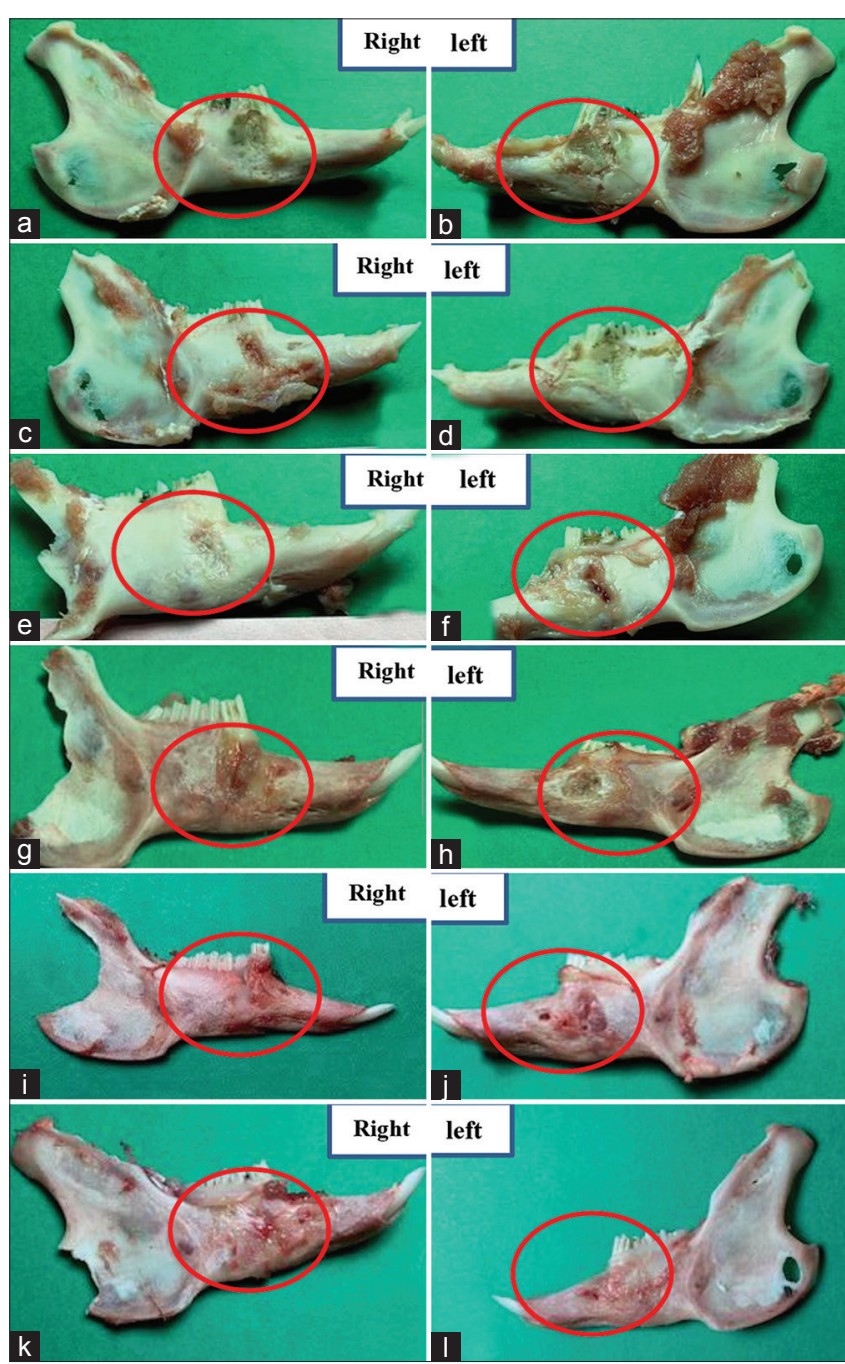

Figure 2: A photo series showing the macroanatomy of the two sides of rabbits after seven days of using materials (Figure a-f) and after 21 days (Figure g-l) A, g: Demineralized Freeze-Dried Bone Allograft (DFDBA), B, h: simvastatin, C, i: PRF, D, j: DFDBA+PRF, E, k: simvastatin+ PRF, F, l: control

\section{Histological findings}

\section{Control group}

Histological examination of the prepared $\mathrm{H}$ and E slides showed variations in new bone formation, fibrous tissue, vascularity, reactive bone formation, osteoblast, and osteoclast cells. After 7 days of the experiment, bone regeneration in the control group was observed only around the defect areas. Moderate inflammation of a defect in the control group was observed. No signs of necrosis were observed (score 0) (Figure 3a). After 21 days, a granulation tissue was clearly noticed. Cartilage-like-tissue was also observed in-between the newly-formed bony trabeculae. Areas, where the active bone formation was taking place, were covered with a large number of osteoblasts (score 2) (Figure 3b).

\section{$D F D B A$ and $D F D B A+P R F$ groups}

After 7 days, the DFDBA sections revealed the presence of new immature bone with areas of blood

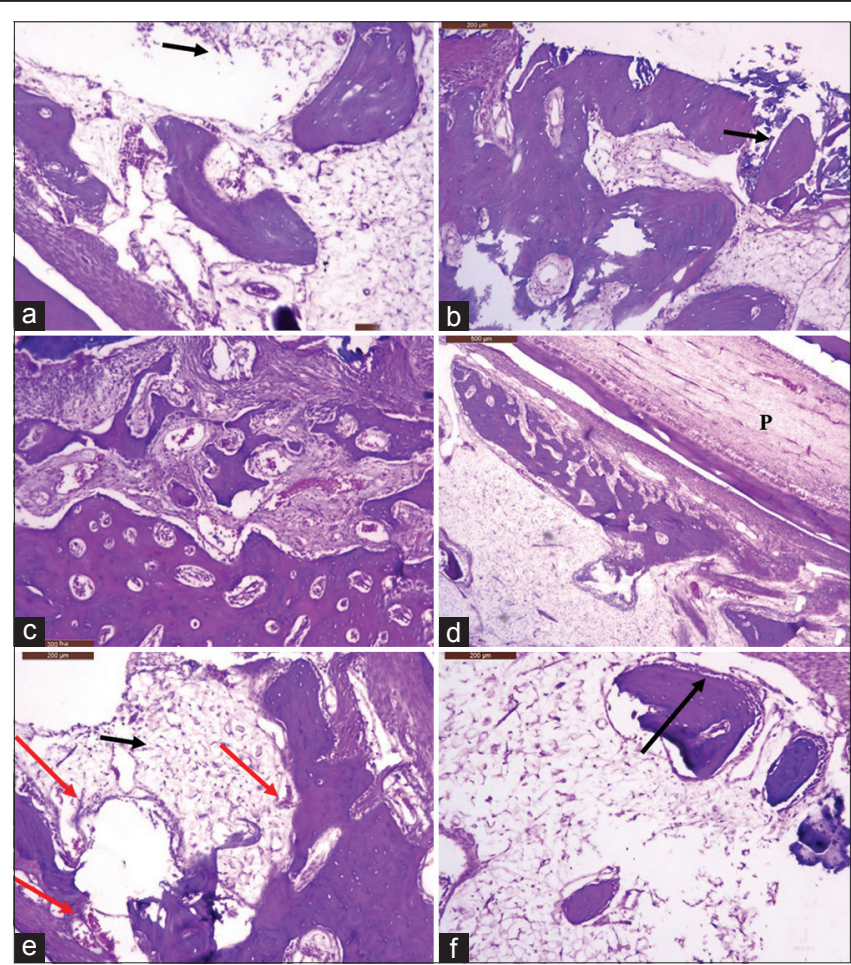

Figure 3: Control group, (a) after 7 days showing empty cavity with some areas of fibrous tissue proliferation, (arrow) (b) After 21 days of normal healing of the control group, presence of granulation tissue and areas of bone fragments in between fibrous c.t with embedded osteocyte, (arrow) (H and Ex100). Demineralized Freeze-Dried Bone Allograft (DFDBA) (c) after 7 days showing the formation of immature bone with the presence of some areas of blood and fibrous areas, notice, the coagulation of blood, fibrocartilaginous type of bone ( $H$ and $E x 200)$, (d) after 21 days showing formed bone in the defect near to pulp of teeth (p) (H and E x100). DFDBA +PRF (e), after 7 days showing well developed organized fibrous tissue (black arrow), extravasation of B.V (Red arrows), areas of bone deposited in the medullary cavity, ( $H$ and Ex 200). (f), after 21 days, section showing osteoblasts that forming a network of bone connected to the reactive trabeculae deposited in the medullary cavity, (arrow), H and E x200

and some inflammation (Figure 3c) score (4), whereas after 21 days, sections showed progression in bone formation around the defect, score (4) (Figure 3d). After 7 days, sections of DFDBA+PRF revealed areas of osteoid bone with areas of blood vessels and background of fibrous tissue score (5) (Figure 3e). After 21 days, areas of bone formation with entrapped osteocytes and osteoblast on the periphery indicate the beginning of bone formation, score (6) (Figure 3f).

\section{Simvastatin and Simvastatin+ PRF Groups}

After 7 days of using simvastatin, sections showed congestion of blood vessels and traces of new bone formation score (3) (Figure 4a). On the other hand, after 21 days, sections showed areas consisting of fibrous more than fibrocartilaginous score (2) (Figure 4b). For Simvastatin + PRF sections, the results showed areas with higher fibrocartilage compared to the fibrous score (3), (Figure 4c). After 21 days, the simvastatin+ PRF group, sections showed faintly stained woven bone with dilated osteocyte lacunae that is neighbored with 
areas of matured bone with undulated resting lines. The reversal line and the resting lines were observed in some areas surrounding the vascular spaces, which reflect that a bone maturation activity is still producing more fibrocartilage areas compared to the fibrous score (3), (Figure 4d).

\section{PRF only}

The examination of PRF sides after 7 days revealed a fibrocartilaginous area within the bone with no signs of necrosis being observed. Sporadic bleeding was observed with a defect reflected in lymphocytic infiltration and moderate initial inflammation (score 1). A loose connective tissue was observed in the defect areas resembling a control group (Figure 4e). After 20 days of using PRF, sections revealed that more fibrous filled the defect compared to the fibrocartilagenous (score 2) (Figure 4f).

\section{Radiographic Evaluation}

Differences in bone densities within each group at different time intervals

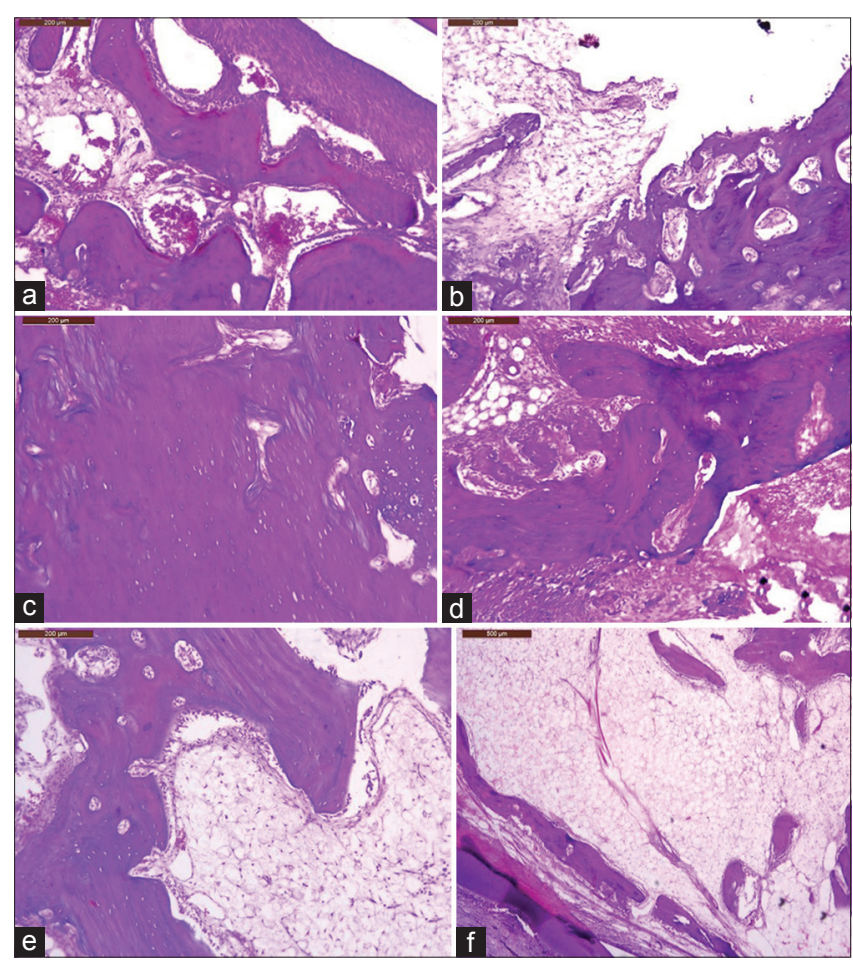

Figure 4: Simvastatin, (a) after 7 days Ice band like reticular bone formation between defect margins ( $H$ and Ex100), (b) after 21 days, showing fibrous tissue within areas of bone formation in between fibrous tissue, $H$ and $E \times 200$. Simvastatin+ PRF, (c) after 7 days, showing the cartilage area within bone with extravasation blood with inflammatory cells and thin bony spicules, $H$ and Ex 100, (d) after 21 days, bone trabeculae, $H$ and $E x$ 40. PRF only, (e) after 7 days showing fibrous c.t network fill the intra-bony defect, $H$ and $E x 100$ ), (f) after 21 days, new-formed bone around the defect with fibrous tissue in between ( $H$ and $E x 40)$
Changes in mean bone density in different groups are presented and compared at different observation periods. There was a statistically significant increase in median bone density from base line to 1 week, 1 week-2 weeks as well as from 2 weeks to 3 weeks in all groups ( $p<0.001)$. In the control groups, there was no statistically significant change in the values of median bone density at different periods.

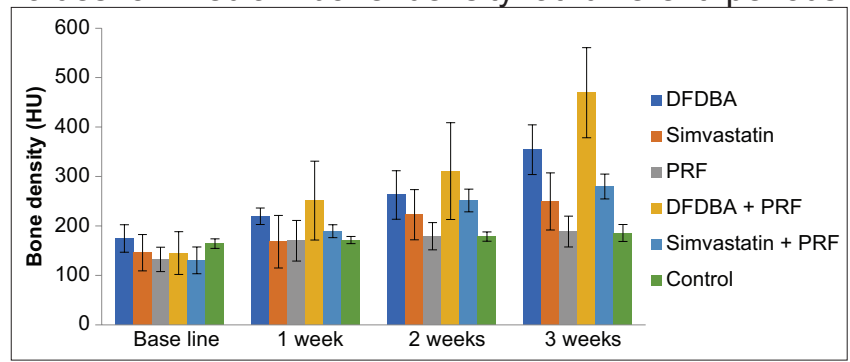

Figure 5: A bar chart representing mean and standard deviation values for bone density
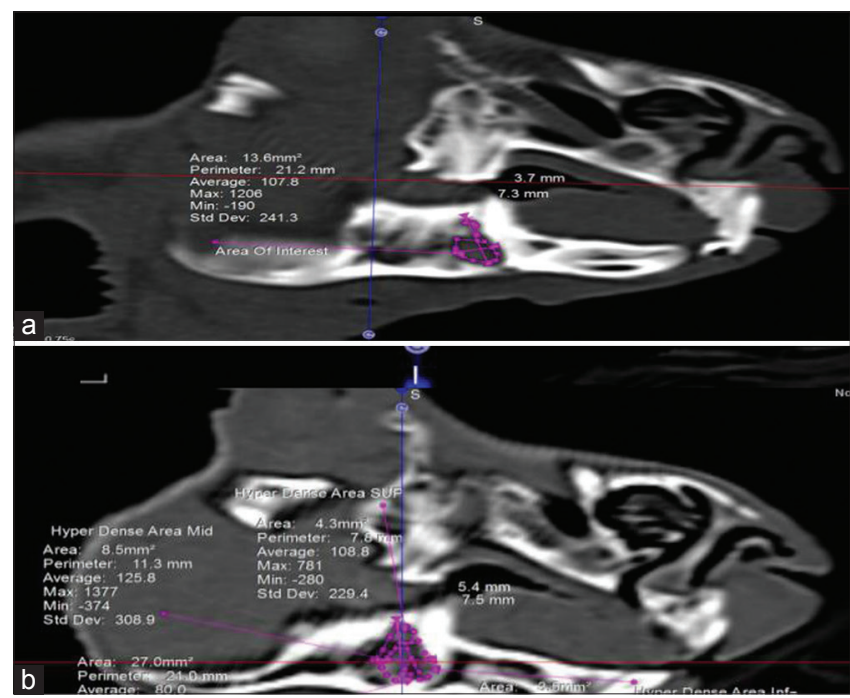

Figure 6: Radiograph of rabbit showing (Demineralized FreezeDried Bone Allograft+PRF) sagittal cut bone window, (a) 2.0(LT), (b) $2.1 \mathrm{~W}(L T)$

Table 3 provides as illustration of the entire results, Figure 5 shows bone density of the different groups and illustrates that the best results in order were the DFDBA+ PRF group, followed by the DFDBA, then the simvastatin, simvastatin + PRF groups then the control group and finally the PRF group. The presented computed tomography revealed that the difference occurred within the best bone density group, which is the DFDBA+ PRF within the examined period. It also showed a decrease in defect size and an increase in bone density (Figures 6 and 7).

\section{Discussion}

The primary aim of the current study was to assess the regenerative power of the DFDBA and simvastatin in conjunction with PRF for the treatment 
Table 3: Descriptive statistics and results of repeated measures ANOVA test for comparison between bone density at different times within each group

\begin{tabular}{|c|c|c|c|c|c|c|c|c|c|c|}
\hline \multirow[t]{2}{*}{ Group } & \multicolumn{2}{|c|}{ Baseline } & \multicolumn{2}{|c|}{1 week } & \multicolumn{2}{|c|}{2 weeks } & \multicolumn{2}{|c|}{3 weeks } & \multirow[t]{2}{*}{$p$-value } & \multirow[t]{2}{*}{ Effect size (Partial Eta Squared) } \\
\hline & Mean & SD & Mean & SD & Mean & SD & Mean & SD & & \\
\hline DFDBA & 174.7 & 27.7 & 219.6 & 16.8 & 262.6 & 49.2 & 354.1 & 50.4 & $<0.001^{*}$ & 0.753 \\
\hline Simvastatin & 145.8 & 36.7 & 168.2 & 53.2 & 222.7 & 50.9 & 249.6 & 57.7 & $<0.001^{*}$ & 0.526 \\
\hline PRF & 132.4 & 24.8 & 170.1 & 41.1 & 179.4 & 27.6 & 188.7 & 31.3 & 0.207 & 0.148 \\
\hline DFDBA+PRF & 145.2 & 43.1 & 251.1 & 79.7 & 310.8 & 97.8 & 469.4 & 91.2 & $<0.001^{*}$ & 0.902 \\
\hline Simvastatin+PRF & 130.6 & 27.1 & 189.4 & 12.9 & 251.4 & 22.9 & 279.7 & 25 & $<0.001^{*}$ & 0.642 \\
\hline Control & 164.3 & 9.5 & 171.4 & 7.2 & 178.7 & 9.4 & 185.6 & 17.2 & 0.794 & 0.036 \\
\hline
\end{tabular}

of induced intra-bony defects. To the best of our knowledge, the study is the first to report on the histological and radiographical regenerative and bone formation effects of macroanatomy of these materials.

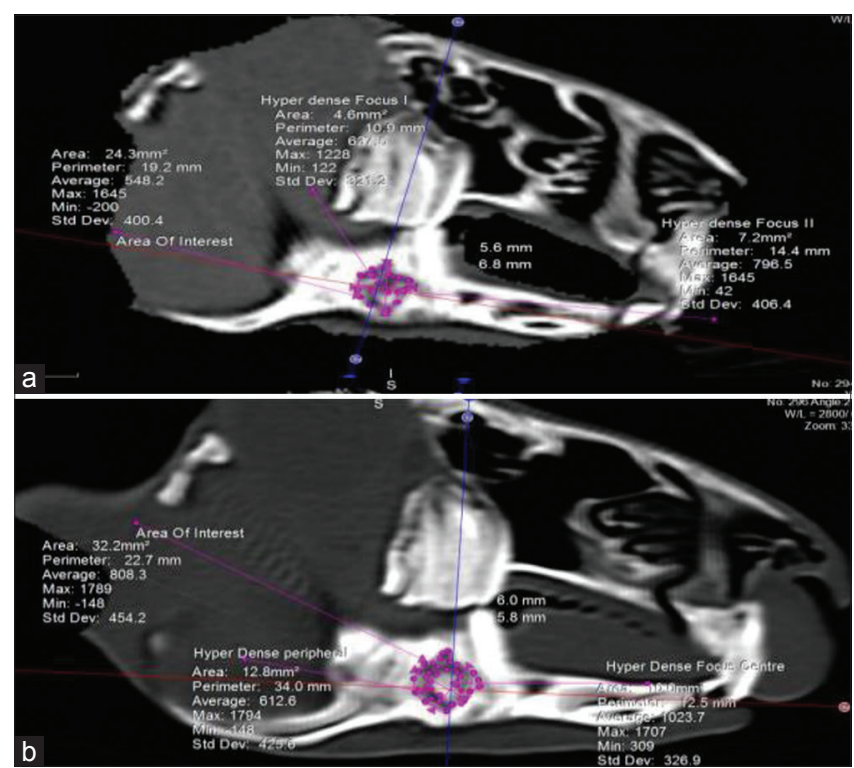

Figure 7: Radiograph of rabbit showing (Demineralized FreezeDried Bone Allograft+PRF) sagittal cut bone window, (a) 2.2(LT), (b) $2.3 W(L T)$

Bone regeneration is a complex, wellorchestrated physiological process of bone formation, which might be seen during normal fracture healing as it integral in continuous remodeling throughout adult life [14]. At present, there is a plethora of various strategies to reinforce the impaired or the "insufficient" bone regeneration process, including the "gold standard" autologous bone graft, free fibula vascularized graft, allograft implantation as well as the use of growth factors, osteoconductive scaffolds, osteoprogenitor cells, and distraction osteogenesis [14]. Most of the present bone regeneration strategies exhibit satisfactory results, yet relatively. Similarly, there are associated drawbacks and limitations to their use and availability. Even more, a number of controversial reports have questioned their efficacy and cost-effectiveness. Up to this point, there are not any heterologous or synthetic bone substitutes available that have superior or potentially identical biological or mechanical properties compared to the bone [15]. The success of bone repair thus depends on the permanence time and the absorption of the material at the site of the bone defect [16].

The rabbit was the animal chosen for this study for a number of valid reasons. It has the advantage that it allows for larger bone defects to easily form compared to rats, mice, or guinea pigs. Moreover, the exclusive use of males avoided the possible hormonal changes present in females because this variable could have threatened the validity of the results. There is an agreement that the cycle of rabbit's bone repair is completed in approximately 42 days. Therefore, our evaluation was carried out in periods of 7 and 21 days, which provided use with a valuable opportunity of analysis in the initial and intermediate stages of bone repair [17], [18]. Future studies are thus needed to evaluate the last stage. Concerning the used design of the animal defect, our intra-bony defect design agreed with [14], who created a bone defect that was regarded as a non-critical injury $(10 \mathrm{~mm}$ diameter and $4 \mathrm{~mm}$ deep) as it removed the cortical layer only. The advantage of this design is that the body would be able to spontaneously and naturally repair itself by replacing the defect with new bone tissue that does not need any specific type of treatment.

DFDBA has been widely used in periodontal therapy and was proven to be a safe material which can induce new bone formation. Our results were following [19], who stated that the DFDBA revealed traces of new bone formation for both 7 days and 21 days. They attributed that the DFDBA has osteoconductive and osteoinductive properties alike and that usage of the DFDBA in various animal studies has proved new bone formation. This accordingly establishes that the DFDBA fulfills the criteria of an ideal graft material as it stimulates the undifferentiated mesenchymal host cells to differentiate into osteoblasts which will eventually lead to bone formation.

In agreement with our results, Simon et al. [20] stated that the use of the PRF with the DFDBA has significant advantages and excellent results compared to the use of the DFDBA alone, after 7 days in socket preservation procedures in four dogs. Moreover, Bölükbaşı et al. [21] observed increasing traces of bone formation following the use of the PRF in 40 days in surgically created defects in sheep tibia. Conversely to our findings though is when they found better bone fill in the PRF groups after 3 weeks in comparison to the DFDBA groups.

However, various in vitro studies have shown a beneficial effect of the PRF on bone healing. Bansal and Bharti [22] also stated that the combination of the PRF with the DFDBA demonstrated better results in probing pocket depth reduction and clinical attachment 
level gain compared to the DFDBA only group in the treatment of periodontal infrasonic defects.

Inconsistent with our results are Shah et al. [23], Agarwal et al. [24], Şimşek et al. [25] who grafted periodontal intra-bony defects with a combination of the PRF and the DFDBA, concluding that the combination showed better results than the DFDBA only group. Therefore, the addition of the PRF to the DFDBA enhanced bone regeneration significantly compared to the bone graft alone because of its enhanced osteoinductive properties. Furthermore, Şimşek et al. [25] revealed that the addition of the PRF to the DFDBA to experimental sites resulted in the use of less nonviable DFDBA (to make room for the $\mathrm{PRF}$ ), and this situation probably caused higher bone formation viability because of less DFDBA in the defect.

In contradiction to our results, Thakkar et al. [26] conducted a clinical and radiological study comparing socket preservation using the DFBDA only or in combination with the PRF. They showed that although the DFDBA is considered an ideal graft material, the combination group with the PRF showed less ridge width. This can be clarified in the use of PRF aids in retaining bone graft material within the walls of the socket for it is a fibrin clot that aids further in the arrest of bleeding.

Simvastatin was repositioned to its anti-inflammatory and osteopromotive purpose recently [27]. Researchers found that simvastatin could accelerate bone regeneration and soft-tissue healing by increasing its osteoblastic differentiation and stimulating neovascularization through its effect on bone morphogenetic proteins and vascular endothelial growth factors [28]. On the $7^{\text {th }}$ day of the experiment, which is the crucial point of the acute phase in treatment, simvastatin's effect was stimulating vascularization. Our findings concurred with these results [29], [30], [31]. Furthermore, the findings of this study agree with other studies [32], [33], [34], which showed increased vascularity with a significantly greater amount of newly formed vessels in the simvastatin group compared to the control group. It can be inferred that, in the acute phase of bone repair, simvastatin had a beneficial effect on stimulating the assembly production of new vessels, which could reflect a bonus for subsequent stages of bone regeneration.

Conversely, Stechow et al. [35], Sonobe et al. [36], Lima et al. [37] did not observe new bone formation induced by simvastatin. They stated that the varying results were clarified in several studies because of different anabolic effects and the bioavailability of simvastatin [38].

In agreement with our results, after 21 days, MacNeill et al. [18] observed intense fibrosis, where there was an increased formation of dense connective tissue that is rich in collagen fibers in the simvastatin group compared to the control group. There was also moderate vascularization and early traces of bone formation with greater scores in the simvastatin group compared to the control group.

Many studies explained that the PRF's regenerative ability in both experimental and clinical studies have been introduced by Rosselli et al. [39]. It is also found that the PRF organizes a dense fibrin scaffold with a high number of leukocytes concentrated on a part of the clot. It permits rapid angiogenesis and a better remodeling of fibrin in more resistant connective tissues. It has also been demonstrated that the PRF is effective in the treatment of periodontal intra-bony defects. In 2013, Choukroun et al. [40] reported that PRF enhances osteogenic lineage differentiation of alveolar bone progenitors more than it does with periodontal progenitors. This occurs by augmenting osteoblast differentiation and mineralized nodule formation via its principal component fibrin, which explains the clinically observed soft-tissue healing properties of PRF. Moreover, it contains various growth factors such as platelet-derived growth factors and insulin-like growth factors, which are found to enhance healing.

Our histological findings with the PRF sections agreed with [41]. Our study time plan was 21 days, which was ideal as Li et al. [41] stated that the PRF shows a sustained release of growth factors in this period. They added that this release continued with a decrease of up to 28 days. This agrees with our results; after 28 days the end of growth factor-releasing period of PRF growth factors probably will leave the defect area, so the effects of the PRF on bone healing will decrease gradually [41].

Various in vitro studies have shown a beneficial effect of the PRF on bone healing through its proliferation and differentiation mark on osteoblasts [42], [43]. Moreover, He et al. [44] conducted an experimental study to indicate the effectiveness of using PRF on bone regeneration in surgical defects that are created in a tibia of a pig. Their histological results showed new bone formation in the defects grafted with the PRF. They added that it was better when mixed with a graft, so the PRF fragments clearly serve as biological connectors of bone particles. Moreover, others clarified that the gradual release of cytokines plays a major role in the self-regulation of inflammatory and infectious phenomena within the grafted material [45], [46].

Within the limitations of this study such as a small sample size and short-term observation, recommendations for future longitudinal studies with larger sample size and utilization of advanced radiological techniques should be carried out to further explore the role and the effect of PRF, simvastatin, and DFDBA in the management of periodontal intra-bony defects. 


\section{Conclusion}

Several studies had shown the advantages and effects of these materials in bone regeneration. All of the examined materials used in this study significantly affected bone regeneration; however, the best results were reserved for the combination of DFDBA + PRF. This combination in particular reflected the best properties of both materials. Hence, based on our results, we can conclude that the use of DFDBA + PRF would be beneficial specifically for bone regeneration and generally for periodontal regeneration.

\section{References}

1. Papapanou PN, Sanz M, Buduneli N, Dietrich T, Feres $M$, Fine $\mathrm{DH}$, et al. Periodontitis: Consensus report of workgroup 2 of the 2017 world workshop on the classification of periodontal and peri-implant diseases and conditions. J Periodontol. 2018;89 Suppl 1:S173-82. https://doi.org/10.1002/jper.17-0721 PMid:29926951

2. Chandran P, Sivadas A. Platelet-rich fibrin: Its role in periodontal regeneration. Saudi J Dent Res. 2014;5(2):117-22.

3. Needleman I, Garcia R, Gkranias N, Kirkwood KL, Kocher T, lorio $\mathrm{AD}$, et al. Mean annual attachment, bone level, and tooth loss: A systematic review. J Periodontol. 2018;89 Suppl 1:S12039. https://doi.org/10.1002/jper.17-0062 PMid:29926956

4. Burleson J, DiPaola C. 3D printing in spine surgery. In: 3D Printing in Orthopaedic Surgery. Amsterdam: Elsevier; 2019. p. 105-22. https://doi.org/10.1016/b978-0-323-58118-9.00010-5

5. Srivastava R, Verma PK, Tripathi V, Tripathi P. Demineralized freeze-dried bone allograft in treatment of interproximal vertical defect - a clinical report. Tanta Dent J. 2016;13(4):213-6. https:// doi.org/10.4103/1687-8574.195719

6. Wei L, Miron RJ, Shi B, Zhang Y. Osteoinductive and osteopromotive variability among different demineralized bone allografts. Clin Implant Dent Relat Res. 2015;17(3):533-42. https://doi.org/10.1111/cid.12118

\section{PMid:23879664}

7. Chauhan AS, Maria A, Managutti A. Efficacy of simvastatin in bone regeneration after surgical removal of mandibular third molars: A clinical pilot study. J Maxillofac Oral Surg. 2015;14(3):578-85. https://doi.org/10.1007/s12663-014-0697-6 PMid:26225047

8. Sezavar M, Bohlouli B, Farhadi S, Tabatabaee S, Latifi R. Simvastatin effects on dental socket quality: A comparative study. Contemp Clin Dent. 2018;9(1):55-9.

PMid:29599585

9. Tsai $\mathrm{CH}$, Shen SY, Zhao JH, Chang YC. Platelet-rich fibrin modulates cell proliferation of human periodontally related cells in vitro. J Dent Sci. 2009;4(3):130-5. https://doi.org/10.1016/ s1991-7902(09)60018-0

10. Gassling V, Hedderich J, Açil Y, Purcz N, Wiltfang J, Douglas T. Comparison of platelet rich fibrin and collagen as osteoblastseeded scaffolds for bone tissue engineering applications. Clin Oral Implants Res. 2013;24(3):320-8. https://doi. org/10.1111/j.1600-0501.2011.02333.x

PMid:22092514
11. Kim CS, Kim CK, Choi SH, Chai JK, Cho KS, Moon IS, et al. Periodontal Repair in surgically created intrabony defects in dogs: Influence of the number of bone walls on healing response. J Periodontal. 2005;75(2):229-35. https://doi. org/10.1902/jop.2004.75.2.229

PMid: 15068110

12. Stuillou $X$, Boutigny $H$, Soueidan $A$, LayrolleP.Experimentalanimal models in periodontology: A review. Open Dent J. 2010;4(1):3747. https://doi.org/10.2174/1874210601004010037 PMid:20556202

13. Emery SE, Brazinski MS, Koka A, Bensusan JS, Stevenson S. The biological and biomechanical effects of irradiation on anterior spinal bone grafts in a canine model. J Bone Joint Surg Am. 1994;76(4):540-8. https://doi. org/10.2106/00004623-199404000-00008

PMid:8150821

14. Dimitriou R, Jones E, McGonagle D, Giannoudis P. Bone regeneration: Current concepts and future directions. BMC Med. 2011;9:66. https://doi.org/10.1186/1741-7015-9-66 PMid:21627784

15. Marsell R, Einhorn T. The biology of fracture healing. Injury. 2011;42(6):551-5. https://doi.org/10.1016/j.injury.2011.03.031 PMid:21489527

16. Ansari M. Bone tissue regeneration: Biology, strategies and interface studies. Prog Biomater. 2019;8(4):223-37. https://doi. org/10.1007/s40204-019-00125-Z PMid:31768895

17. Schmitz JP, Hollinger JO. The critical size defect as an experimental model for craniomandibulofacial nonunions. Clin Orthop Relat Res. 1986;205:299-307. https://doi. org/10.1097/00003086-198604000-00036

PMid:3084153

18. MacNeill SR, Cobb CM, Rapley JW, Glaros AG, Spencer P. In vivo comparison of synthetic osseous graft materials. A preliminary study. J Clin Periodontol. 1999;26(4):239-45. https:// doi.org/10.1034/j.1600-051x.1999.260407.x

PMid:10223395

19. Gawish A, Shalby H, Ghoniem M, Selim M. The effect of autologous bone marrow concentrate and demineralized freezedried bone allograft in management of experimentally induced intrabony periodontal defects in rats (immunohistochemical and radiographic study). Egypt Dent J. 2018;64(1):287-300. https:// doi.org/10.21608/edj.2018.77081

20. Simon BI, Zatcoff AL, Kong JW, O'Connell SM. Clinical and histological comparison of extraction socket healing following the use of autologous platelet-rich fibrin matrix (PRFM) to ridge preservation procedures employing demineralized freeze dried bone allograft material and membrane. Open Dent J. 2009;3:929. https://doi.org/10.2174/1874210600903010092 PMid: 19543550

21. Bölükbaşı N, Yeniyol S, Tekkesin MS, Altunatmaz K. The use of platelet-rich fibrin in combination with biphasic calcium phosphate in the treatment of bone defects: A histologic and histomorphometric study. Curr Ther Res Clin Exp. 2013;75:1521. https://doi.org/10.1016/j.curtheres.2013.05.002 PMid:24465037

22. Bansal C, Bharti V. Evaluation of efficacy of autologous plateletrich fibrin with demineralized-freeze dried bone allograft in the treatment of periodontal intrabony defects. J Indian Soc Periodontol. 2013;17(3):361-6. https://doi.org/10.4103/0972-124x.115663 PMid:24049338

23. Shah M, Patel J, Dave D, Shah S. Comparative evaluation of platelet-rich fibrin with demineralized freeze-dried bone allograft in periodontal infrabony defects: A randomized controlled clinical study. J Indian Soc Periodontol. 2015;19(1):56-60. https://doi. 
org/10.4103/0972-124x.145803

PMid:25810594

24. Agarwal A, Gupta ND, Jain A. Platelet rich fibrin combined with decalcified freeze-dried bone allograft for the treatment of human intrabony periodontal defects: A randomized split mouth clinical trail. Acta Odontol Scand. 2016;74(1):36-43. https://doi. org/10.3109/00016357.2015.1035672

PMid:25972081

25. Şimşek S, Özeç İ, Kürkçü M, Benlidayı E. Histomorphometric evaluation of bone formation in peri-implant defects treated with different regeneration techniques: An experimental study in a rabbit model. J Oral Maxillofac Surg. 2016;74:1757-64. https:// doi.org/10.1016/j.joms.2016.05.026

PMid:27351696

26. Thakkar D, Deshpande NC, Dave DH, Narayankar SD. A comparative evaluation of extraction socket preservation with demineralized freeze-dried bone allograft alone and along with platelet-rich fibrin: A clinical and radiographic study. Contemp Clin Dent. 2016;7(3):371-6. https://doi. org/10.4103/0976-237x.188567

PMid:27630503

27. Maeda T, Matsunuma A, Kurahashi I, Yanagawa T, Yoshida H, Horiuchi $N$. Induction of osteoblast differentiation indices by statins in MC3T3-E1 cells. J Cell Biochem. 2004;92(3):458-71. https://doi.org/10.1002/jcb.20074

PMid: 15156558

28. Gupta S, Del Fabbro M, Chang J. The impact of simvastatin intervention on the healing of bone, soft tissue, and TMJ cartilage in dentistry: A systematic review and meta-analysis. Int J Implant Dent. 2019;5(1):17. https://doi.org/10.1186/s40729-019-0168-4 PMid:30963362

29. Thylin MR, Mcconnell JC, Schmid MJ, Reckling RR, Ojha J, Bhattacharyya I, et al. Effects of simvastatin gels on murine calvarial bone. J Periodontol. 2002;73(10):1141-8. https://doi. org/10.1902/jop.2002.73.10.1141

PMid: 12416771

30. Wong RW, Rabie AB. Early healing pattern of statin-induced osteogenesis. Br J Oral Maxillofac Surg. 2005;43(1):46-50. https://doi.org/10.1016/j.bjoms.2004.08.014

PMid: 15620774

31. Chuang SC, Liao HJ, Li CJ, Wang GJ, Chang JK, Ho ML. Simvastatin enhances human osteoblast proliferation involved in mitochondrial energy generation. Eur J Pharmacol. 2013;714(13):74-82. https://doi.org/10.1016/j.ejphar.2013.05.044 PMid:23769741

32. Wong RW, Rabie AB. Statin collagen grafts used to repair defects in the parietal bone of rabbits. $\mathrm{Br} \mathrm{J}$ Oral Maxillofac Surg. 2003;41(4):244-8. https://doi.org/10.1016/s0266-4356(03)00081-0 PMid: 12946667

33. OzeçI,KiliçE, GümüşC,GözeF.Effectoflocalsimvastatinapplication on mandibular defects. J Craniofac Surg. 2007;18(3):546-50. https://doi.org/10.1097/scs.0b013e318052ff05

PMid:17538316

34. Oliveira KA, Zecchin KG, Alberici LC, Castilho RF, Vercesi AE. Simvastatin inducing $P C 3$ prostate cancer cell necrosis mediated by calcineurin and mitochondrial dysfunction. J Bioenerg Biomembr. 2008;40(4):307-14. https://doi.org/10.1007/ s10863-008-9155-9

PMid:18679777
35. StechowD, Fish S, Yahalom D, Bab I, Chorev M, Müller R, etal. Does simvastatin stimulate bone formation in vivo? BMC Musculoskelet Disord. 2003;4:8. https://doi.org/10.1186/1471-2474-4-8 PMid: 12718758

36. Sonobe M, Hattori K, Tomita N, Yoshikawa T, Aoki H, Takakura Y, et al. Stimulatory effects of statins on bone marrow-derived mesenchymal stem cells. Study of a new therapeutic agent for fracture. Biomed Mater Eng. 2005;15(4):261-7. PMid:16010034

37. Lima CE, Calixto JC, Anbinder AL. Influence of the association between simvastatin and demineralized bovine bone matrix on bone repair in rats. Braz Oral Res. 2011;25(1):42-8. https://doi. org/10.1590/s1806-83242011000100008 PMid:21359450

38. Mah J, Hung J, Wang J, Salih E. The efficacy of various alloplastic bone grafts on the healing of rat calvarial defects. Eur J Orthod. 2004;26(5):475-82. https://doi.org/10.1093/ ejo/26.5.475 PMid: 15536835

39. Rosselli JE, Martins DM, Martins JL, Oliveira CR, Fagundes DJ, Taha MO. The effect of simvastatin on the regeneration of surgical cavities in the femurs of rabbits. Acta Cir Bras. 2014;29(2):8792. https://doi.org/10.1590/s0102-86502014000200003 PMid:24604311

40. Choukroun J, Adda F, Schoeffler C, Vervelle A. An opportunity in paro-implantology: PRF. Implantodontie. 2001;42:55-62.

41. Li Q, Pan S, Dangaria S, Gopinathan G, Kolokythas A, Chu S, et al. Platelet-rich fibrin promotes periodontal regeneration and enhances alveolar bone augmentation. Biomed Res Int. 2013;2013:638043. https://doi.org/10.1155/2013/638043 PMid:23586051

42. Zumstein MA, Rumian A, Thélu CÉ, Lesbats V, O'Shea K, Schaer M, et al. SECEC Research Grant 2008 II: Use of platelet- and leucocyte-rich fibrin (L-PRF) does not affect late rotator cuff tendon healing: A prospective randomized controlled study. J Shoulder Elbow Surg. 2016;25(1):2-11. https://doi. org/10.1016/j.jse.2015.09.018 PMid:26687471

43. Ehrenfest D, Rasmusson L, Albrektsson T. Classification of platelet concentrates: From pure platelet-rich plasma (P-PRP) to leucocyte- and platelet-rich fibrin (L-PRF). Trends Biotechnol. 2009;27(3):158-67. https://doi.org/10.1016/j.tibtech.2008.11.009 PMid:19187989

44. He L, Lin Y, Hu X, Zhang Y, Wu H. A comparative study of plateletrich fibrin (PRF) and platelet-rich plasma (PRP) on the effect of proliferation and differentiation of rat osteoblasts in vitro. Oral Surg Oral Med Oral Pathol Oral Radiol Endod. 2009;108(5):70713. https://doi.org/10.1016/j.tripleo.2009.06.044 PMid:19836723

45. Yilmaz D, Dogan N, Ozkan A, Sencimen M, Ora BE, Mutlu I. Effect of platelet rich fibrin and beta tricalcium phosphate on bone healing. A histological study in pigs. Acta Cir Bras. 2014;29(1):5968. https://doi.org/10.1590/s0102-86502014000100009 PMid:24474179

46. Simonpieri A, Del Corso M, Sammartino G, Dohan Ehrenfest DM The relevance of Choukroun's platelet-rich fibrin and metronidazole during complex maxillary rehabilitations using bone allograft. Part I: A new grafting protocol. Implant Dent. 2009;18(2):102-11. https://doi.org/10.1097/id.0b013e318198cf00

PMid:19359860 